811.163.41'38

821.163.41.09-6"1914/1918":81'42 https://doi.org/10.18485/sj.2019.24.1.10

МИЛАНКА Ј. БАБИЪ ${ }^{*}$

Универзитет у Источном Сарајеву

Филозофски факултет Пале
Оригинални научни рад

Примљен: 11. 09. 2018.

Прихваћен: 15. 01. 2019.

\title{
О ОСОБИНАМА ЕПИСТОЛАРНОГ ДИСКУРСА У ПИСМИМА ВОЈНИКА И ЛОГОРАША ИЗ ПРВОГ СВЈЕТСКОГ РАТА
}

У раду се са структурно-стилистичког и прагматичког аспекта анализира лична преписка српских војника, ратних заробљеника који су се током Првог свјетског рата нашли у логорима Аустроугарске монархије, као и Срба аустроугарских војника, који су пребјегли у Србију или у Русију, или су тамо заробљени. Дескриптивно-структуралном методом, уз уплитање и когнитивно-концептуалне, издвајају се типични дискурс-маркери и тумачи њихова структура и значења у ширем социокултурном и тематском кругу - у коме се издвајају и концептуализују топоси заробљеника, породице, брака и патриотизма.

Кључне ријечи: епистоларни дискурс, жанр, адресат, адресант, топос, еналага лица

\section{1. УВОД}

Епистоларни дискурс, као специфична дијалошка форма коју карактерише просторно-временска дистанцираност комуникатора, формира се увијек тако да идентификовање тог локационог оквира комуникације спада у његове типичне дискурс-маркере, као и да улоге адресанта и адресата учини видљивим не само у контексту конкретног писма него и у ширем социокултурном контексту за који је типичан одређени модел преписке. У таквом дијалогу

*rasovaca@yahoo.com 
нужно је супериорна улога адресанта, а тиме и његова тачка гледишта, па се из адресантове перспективе обликује слика свијета коју епистоларна форма рефлектује. Писма једног адресанта изражавају у општем смислу субјективну слику свијета, једно виђење ствари и појава преломљено кроз мисаоно-доживљајни свијет појединца које као такво не може бити универзално за одређено вријеме и друштво. Насупрот тој индивидуално-интимистичкој функцији писма, издвајају се писма различитих адресаната која, обједињена настанком у истим друштвеним околностима и истим тематским кругом, обликују за дато вријеме и дате појаве универзално-објективну слику свијета и када су појединачно интимне природе. Поглед на свијет у оквиру тако формираног циклуса не успоставља се у дијалогу на релацији адресант - адресат, него у полифонијском дијалогу гласова, свијести и тачки гледишта различитих адресаната као аутодијегетичких наратора ${ }^{1}$, који непосредно доживљавају ситуацију коју у форми писмима обликују. Један такав тематски круг који успоставља друштвено универзална значења формиран је у типичном хронотопу Првог свјетског рата и његових стратишта, па корпус анализе у овом раду представља поновљено издање збирке писама - Српска писма из светског рата 1914-1918, која је током рата сакупио и 1923. године у Српској штампарији у Осијеку објавио др Владислав Пандуровић. Он је од марта 1915. године био цензор војничких писама у одјељењу организованом при аустријском Црвеном крсту, привидно ради обавјештавања о ратним заробљеницима, али је суштински под контролом ратног министарства Монархије служило за војничку шпијунажу и откривање података о распореду и плановима српских војних снага. Као цензор, прочитао је око 30.000 српских писама „из свих крајева васцелог Српства” и врло брзо је „запазио да у њима лежи народно благо, које би сачувати требало", али пошто су у његовој групи за цензуру били „све сами Хрвати, чије расположење према Србима почетком рата није било баш најбоље" (Пандуровић 2014: 6), морао је да се самостално сналази да би тајно преписао писма која су се задржавала или остајала на цензури. Послије му је у томе помогао сарадник у цензорској групи Антон Потурчић, Србин католик, а након што је постао војни консултант, и Хрват римокатолик из Лике А. фон Р., те ,један прикривени Чех, Јохан Прехтл” и двојица „добрих Словенина" - Хрват др Рудолф Бан и Словак др Милан Хопа, обојица у одређеним периодима старјешине у хрватској групи за цензуру. Др Пандуровић је преписивао писма „без икакве преинаке, дословице онако како их је поједини писац написао" (Пандуровић 2014: 8), трудећи се да сачува све дијалекатске и ортографске специфичности оригинала. Он наглашава да се из писама јасно види „како је добро примењено правило Вука Караџића: пиши онако као што говориш" (Пандуровић 2014: 8), те да су Срби понајвише писали ћирилицом,

${ }^{1}$ Аутодијегетички наратор јесте онај који је протагониста догађаја о којима саопштава (в. Принс 2011: 37) 
а латиницом у случајевима „забране ћирилице, или што су такво искуство имали, да им латиницом писано писмо пре стигне” (Пандуровић 2014: 9). У збирци су сабрана писма војника и официра упућена члановима уже и шире породице, рођацима и пријатељима, (рјеђе службама и институцијама), као и писма која су од њих добијали. Та разноврсност на релацији пошиљалац - прималац подразумијева специфичности језичког израза и унутаржанровске типолошке специфичности, те омогућује да се, поред фактографских елемената о којима писма и свједоче и приповиједају, из њих ишчита и мноштво информација не само о ставовима, интелектуалном и емоционалном стању појединца него и његовом социјалном, класном и територијалном статусу. Писма су, дакле, глобално-тематски, временски и функционално обједињена, па се посматрају кроз карактеристичне елементе епистоларно-приповједачког стила, са типичним дискурс-маркерима епистоларне форме, дијалошких, конекторских, експресивно-емоционалних и прагматичких функција у датим околностима.

Структурно-функционалне и прагматичке специфичности писма - које се прије свега огледају у успостављању писмене комуникације између просторно-временски удаљених комуникатора, с циљем преношења обавјештења, мисли, жеља, осјећања и захтјева, те у иницијативи пошиљаоца да изазове реакцију примаоца и добије повратнау информацију - сврставају писмо у говорни жанр, гдје га убраја и Бахтин, будући да писмо увијек, иако пошиљалац и прималац нису у односу лицем у лице, укључује другога или адресата у исказ „од кога очекује одговор, активно узвратно разумевање” (Бахтин 1980: 265), предвиђа његову улогу и начин реаговања. У тој говорној интеракцији учесници слиједе устаљена „формативна правила епистоларног дискурса” (в. Поповић 2000: $20)$, која подразумијевају наизмјеничност размјењивања порука, засновану на постојању одређеног заједничког знања о свијету, заједничких интереса који вежу пошиљаоца и примаоца, као и на њиховом међусобно одређеном статусу, симетричном - када се ради о комуникаторима истог социјалног статуса (брачни другови, чланови породице, пријатељи) - или асиметричном - када су пошиљалац и прималац у хијерархијски поларизованим улогама (у корпусу је заступљен мањи број писама са субординираном улогом пошиљаоца у којима се он обраћа некој хиперординираној инстанци - краљу, команди, институцији Црвеног крста и сл.). Преписка се реализује у оквиру конвенционализоване форме, која предодређује: мјесно-временску локализацију адресанта, будући да се ради о ратним заробљеницима или војницима који се често премјештају; стратегије отварања и затварања комуникације, поздрављања и опраштања, као дискурсних маркера почетка и краја; облике подстицања дијалошке интеракције - пошиљалац очекује и експлицитно тражи одговор примаоца; моделовања поруке као нарације о елементима стварности непознатим адресату; формуле захваљивања, извињења, честитања, молбе, позива, и сл. 
Фамилијарно-интимни тип писама и ситуација насилне раздвојености комуникатора у апокалиптичним околностима предодређују да у анализираном корпусу, уз конвенционалне, доминира и мноштво индивидуално-емоционалних и субјективно-оцјењивачких ставова адресанта и према предмету говора и према адресату, што се реализује и јединицама лексичко-семантичке и јединицама (морфо)синтаксичко-семантичке експресивности. Степен емоционалности зависи од типа односа међу комуникаторима - изразитији је у преписци између брачних другова, синова и родитеља, браће, мање емоционалан између пријатеља и комшија - а условљен је изразито и социјалним статусом и нивоом образованости, тј. много је емоционалнија и језичко-стилски експресивнија преписка припадника сељачког сталежа него официра. Експресивношћу израза маркирана су и писма упућена на адресе институција или службених лица, јер одражавају обраћање из нужде, молбу за испуњавањем адресантовог захтјева или његову евалуативно-апелативну поруку о егзистенцијалној угрожености и тешким условима у којима бораве ратни заробљеници. Зато је анализа вишеаспекатска - у основи структурно-стилистичког карактера, јер се односи на језичке јединице и конструкције као формативне елементе епистоларног дискурса и њихове прагматичко-стилистичке варијације у датом корпусу. Осим тога, анализа је и когнитивно-концептуалног карактера, будући да се концептуализују одређени топоси - као „стабилне диспозиције мотива које се учестало појављују" у тексту (в. Принс 2011: 206), а у писмима из Првог свјетског рата посебно су типични мотиви заробљеника, породице, брака и патриотизма који се концептуализују у оквиру патријархално-православног система вриједности српског друштва с почетка XX вијека.

\section{2. ТИПИЧНИ ЕЛЕМЕНТИ СТРУКТУРЕ ПИСМА И ЊИХОВА ЗНАЧЕЊА}

Будући да је писмо тип дијалошког текста у коме су саговорници просторно-временски удаљени, експлицирање тог оквира спада у формативне елементе структуре писма уопште. Одреднице времена и простора у војничким писмима, односно у писмима упућеним војницима или заробљеницима, налазе се на почетку текста. Лоцирање писама у простору и времену адресанта досљедно је проведено у војничким писмима, посебно у писмима из заробљеништва, док је у женским писмима из Србије најчешће назначен само датум. Прагматика комуникације сеоске жене намеће датирање писма, да би адресат имао информацију да ли је писмо стигло или није, будући да се писма врло често загубе током цензуре. Информација о мјесту подразумијева завичај и дом адресата и редундантног је карактера за тај тип адресанта, па зато и изостаје. Пошто представу о времену у датом социокултурном контексту условљавају два календара - православни јулијански и општеприхваћени грегоријански, 
датум је у писмима жена и војника сељака одређен врло често према „црквеном” или „нашем” календару или двоструко:

Писано писмо 8. јунија намег. 21; Писано писмо намег 21. јуна, 4. јула немачког, од твога друга Јеле... 17.

У писмима заробљеника и војника, а посебно официра, без обзира на породични или пословни карактер писма, успоставља се на почетку комуникације обавезно просторно-временски оквир. Лоцирање писма логораша и војника према мјесту боравка нужан је дио информације, будући да се и једна и друга категорија у току трајања тог стауса више пута премјешта. Вријеме је одређено разноврсно с обзиром на каледаре, најчешће према грегоријанском:

Тоикоје (Самарска губ.), 3. маја 1916. 51; Гредиг, 13. јуна 1915. 59; Болдогасою, 24. јуна 1915. 61; Ронов (Ческа), 11. маја 1916. 75; Drosendorf, 30/VII 1917. 89; Kavna, z. P. Selend, Arad žup., 23/VI. 1917. 88.

У једном броју писама наводе се датуми по оба календара - да би адресат добио поуздану информацију, с обзиром на то да ли користи један или други календар:

Гердиг код Салибурга, 2.-15. јула 1916. 77; Гредиг, 14., 27. августа 1915. 67; Nagybörzsöny (Hont megye), 15. 28./V. 1917. 87; 18. нашег септемб. 1917., ниног првог. 90.

Ако су датирана по јулијанском календару, писма садрже ознаку која упућује на тако одређено вријеме:

Соликамск, 26. јуна 1915. n. ст.; Ниш, 1. октобра 1915. (n. ст.). 121; Криви Вир, Бољевач, 21. јула 1915. л. ст.113.

Скраћеницама n. cm. =,по старом” или л. cm. =,лета старог” прецизира се временски оквир писма, а наглашавање јулијанског календара упућује на православно-патриотску свијест адресанта, на чување идентитета у туђем непријатељском свијету, оличеном и у супротстављеном „немачком” или „њином” датуму, наспрам ,нашег”.

У типичне дискурсне маркере епистоларног жанра убрајају се „тзв. терминалне формуле, тј. формуле" које одређују почетак и крај текста (Поповић 2000: 119). То су најчешче форме поздрављања којима се успоставља и завршава комуникација. У форме поздрављања нужно су укључене форме обраћања - просте или врло развијене вокативне или номинативне конструкције које изражавају граматику друштвеног статуса иманентну времену у коме су писма настала, нужно обиљежену патријархалним културним кодом породичних односа у писмима фамилијарног типа или нормама друштвено хијерархизованих односа, у мањем броју пословних писама.

Типичност обраћања у питањима фамилијарног типа одређена је породичним или пријатељским односима пошиљаоца и примаоца, тј. да ли је у питању обраћање између супружника или између синова и родитеља или 
између браће или обраћање пријатељима и познаницима. У оквиру тих односа разликују се сељачка и грађанска писма, те војничка и официрска, а нарочито женска и мушка писма. Неутралније форме, типичне и за савремени тип обраћања са атрибутима емпатијске и посесивно-интимистичке природе уз антропоним (Драга Јоко, 43; Драга Тодо, 50; Драги Милане, 243) или уз апелатив са значењем породичних односа (Мила Сестро, 16; Мила Сејо, 221; Драга мајко, 84; Драга мајко и сестре, 76; Драги и поштовани отаи, 75; Драги родитељи, 233; Драги Куме, 77), те комбинације атрибута, апелатива-атрибутива и имена (Драги сине Лука, 113; Мила сејо Драго, 150; Драги Брате Мито, 113; Драги и мили зете Никола, 132), као и супстантивно употријебљеног посесива и атрибута (Мила моја, 71; Драги моји, 117), и сл. - типичније су за мушка него за женска писма, посебно за официрска.

Све те форме могу бити у зависности од емоционалног и психолошког стања адресанта развијене са већим бројем атрибутских додатака и координативних конструкција којима се исказује блискост и љубав пошиљаоца према примаоцу или примаоцима - члановима породице, нпр.:

Драга Миленија, Јелена и Даница - мила дечице моја!,74; Драги и мили сине мој Каменко и слатко чедо моје, и Ружище, моја мила ћерчице, здраво да сте. 49.

У писмима заробљеника члановима уже породице, посебно дјеци, врло честа су у формама ословљавања и амлификативно-апозицијска нагомилавања, с циљем да се о истом референту изнесе што више различитих појединости којима се изражава милошта и њежност. Тај тип нагомилавања подразумијева референцијалну синонимију, контекстуално преименовање референта, што је карактеристика амплификације као стилског средства (в. Ковачевић 2000: 152), а чешће се јавља у писмима војника сељака нпр.:

Каменко, мој рођени сине, првенче мој, прва велика радости моја, кад пођеш кући у Арадаи, ти уз пут сврати на гробље...50.

Писмо упућено сину-првенцу истовремено је и израз не само излива осјећања него и наглашавања да је син-првенац истовремено и син-насљедник, од кога се очекује да у условима када је отац у заробљеништву преузме улогу и обавезе домаћина.

У писмима супржника, у писмима жена мужевима, патријархални односи који намећу прикривање интимности условљавају и поздрављање апелативом друже:

Драги друже мој, враћа ти се поздрав на речи твоје што си ме искрено поздравио у Митино писмо... 20.

Ословљавање супруга синтагмом драги друже мој условљено је лексиколошким значењем да су супружници „брачни другови”. Тај назив је био уобичајен у социјалистичком друштву, док је у времену Првог свјетског рата употреба апелатива друг за супружника темељније заснована на значењу „1.а. 
искрен, присан пријатељ, благонаклон, близак, одан човек” (РСАНУ 1966, IV, $741)$ и подразумијева заједницу повјерења и међусобне подршке и блискости. Зато се уз овај апелатив често јавља и придјев рођени:

А и, друже рођени и мили мој Тошо, твоје речи млоге Соса спомиње... 20.

Неријетко и се супституишу у истом контексту именице друг и брат:

Тошо, прими ожалошћени поздрав од твога дрга, од твоје Зорке. Брате мој, и друже мој слатки, и усрдни, слатко те поздрављам. 15.

У датом контексту актуализује се фамилијарношћу маркирано значење именице брат - „пријатељ, друг; човек у односу према другим људима”, које у вокативу, у комбинацији са замјеницом мој, најчешће у инверзији, представља „узречицу у присном обраћању или разговору” (РМС 2007: 107). И један и други апелатив у слици свијета комуникатора концептуализују брак као заједницу блискости, оданости и пријатељства, али то нису једини домени који одређују цјеловиту представу или сценариј брака. Ословљавање између супружника вокативом друже или друже рођени, брате или брате мој у писмима је чест начин, али није уопштен као клише, посебно у писмима жена, јер у условима раздвојености, у условима угрожености живота, проговара чежња у разноврсним изливима њежности, па се у поздравну формулу укључује и одговарајућа лексика (мили мој, 20; слатки мој, 15 и сл.), што брак одређује и доменом припадања у љубави и њежности. Придјев слатки у основном значењу актуализује домен брачне сласти - брака као посластице („сладак, слатка, -о 1. који има укус меда, шећера, зрелог воћа и сл.” РМС 2007: 1237), али у ширем контексту различитих писама основно значење придјева слатки блиједи и он такође појачава домен блискости, будући да се у развијеним фомама обраћања често јавља не само у обраћању између супружника него и у обраћању између сродника, гдје има значење „мио, драг” у присном обраћању (PMC 2007: 1237):

Примите искрен поздрав од вамег сина Стевана, слатког Радиног баие [...] Сад поздрављам мога слатког и рођеног брата Љубу. 41.

Ословљавање, као формула с почетка писма, у писмима жена сељанки врло често се поновља у структури писма, са конекторском или фатичком функцијом, као маркер почетка новог пасуса и увођења новог референта којим се изражавају информације о претходној преписци, о „картама” које су претходно стигле од адресата или их адресант није примио, о осјећањима туге, чежње, љубави, о дјеци и укућанима, о кућним пословима, о родбини и пријатељима итд.:

Чедо, друже мој, прими искрен поздрав од твога сирочета Јеле...

Чедо друже мој, мили мој Чедо, ја сам твоју карту примила...

Чедо, друже, мој верни друже, Чедо, здраво ми је тешко...

Чедо брате, сад да ти кажем шта кући радимо... 
Чедо, брате мој, Чедо, Чедо друже мој, незаборављени Чедо, мој лепи Чедо, Чедо друже, мој зажељени Чедо, са'те млого поздравља твој друг Јела са далека...

Чедо, друже мој, Чедо, Чедо, мој мили Чедо, незаборављени мој Чедо, здраво ми је тешко живити на ову бригу велику... 17-19.

Ове вокативне конструкције показују да је и у овом писму у ословљавању заступљена лексика која представља вриједносни систем блискости, повјерења и поштовања у браку, што репрезентују апелативи друг и брат, као и емоционално-интимна стања припадања (мој), заљубљености, чежње и оданости (лепи, мили, зажељени, верни, незаборављени).

У писмима заробљеника и војника упућеним породици у цјелини, као широј заједници коју, уз њихове супруге и дјецу, чине и њихови родитељи, браћа и њихове породице, форме обраћања исказују се кроз појединачна именовања и поздраве који усложњавају структуру писма - сваким новим поздравом отвара се нови домен породичног живота:

Примите искрен поздрав од вамег сина Стевана, слатког Радиног баие.

Сад поздрављам мога слатког и остарелог лалу, који нашу слатку кућу чува, и моју слатку мајку и рођену, валда је и она Бога молила за юене рођене синове и за њене слатке ранитеље.

Сад поздрављам мога слатког и рођеног брата Љубу. Ја до њега још нисам дошо, валда ће бог дати...

И поздрављам мога верног друга Мару, која моју и њену слатку деиу чува, и моју снаву Даринку. Пази и чувај твоју слатку деиу и мога слатког и рођеног сина Раду. Слушај Радо твога слатког деду...

И моју слатку и рођену синовичу Невенку...

И моју слатку и рођену ћерку Катииу...

И поздрављам мога стрица чичу, и моју стрину Нину и Радованчеве и све панчевачке све, и сву мију родбину, и сву моју фамилију, и све моје комиије и ове и оне. Ја ји све поздрављам. 41.

У патријархалном коду структура породице је хијерархијски одређена - по старини, према мушким члановима, па поздрављање најприје укључује адресантовог оца (поздрављам мога слатког и остарелог лалу), главу породице која се одређује доменом куће као родног дома. У породици влада поштовање и топли односи, па је у средишту синтагме именовања адресата емоционално маркирана именица лала као „назив одмила, из милоште за мушку особу (старијег мушкарца у кући, оца, старијег брата, момка и др)" (РMC, 626). Потом се поздравља мајка, брат, а онда супруга, снаха и дјеца, међу којом се нарочито истиче син-насљедник (Примите искрен поздрав од вамег сина Стевана, слатког Радиног баче; Пази и чувај твоју слатку деиу и мога слатког и рођеног сина Раду. Слушај Радо твога слатког деду), а на крају и шира родбина и комшије. Тим кумулативним набрајањем, обједињеним катафорски замјеницом све ( $\mathrm{а} \mathrm{ји} \mathrm{све} \mathrm{поздрављам)} \mathrm{изражава} \mathrm{се} \mathrm{поштовање}$ према наведеним адресатима и чежња адресанта за домом и завичајем. Однос према супрузи одређен је доменом ослонца у подизању породице и брижног 
материнства (која моју и юену слатку децу чува), те чувара патријархалне породичне традиције - усмјерене на наглашену посвећеност у бризи за сина-насљедника (Пази и чувај твоју слатку децу и мога слатког и рођеног сина $P a \partial y)$. Колико је син-насљедник у ланцу породичних односа значајнији од остале дјеце, показује и представљање адресанта у иницијалном поздраву улогом сина својих родитеља и оца - баце (баца је хипокористик лексеме баба, односно отаи, в. РСГВ 2000: 85) свога сина Раде (Примите искрен поздрав од вашег сина Стевана, слатког Радиног бац̧е). Одрживост породице на кућном огњишту посебно је значајна у временима великог страдања народа, па у тренутку када је адресантова улога неизвијесна, он апострофира темељ породице - своје родитеље, и њену будућност - свога сина-насљедника од кога очекује да - када њега нема - буде директна повезница са претходним кољеном (Слушај Радо твога слатког деду). Тако се концептуализује породица као генерацијски ланац у коме се традиција преноси са оца на сина или - у случају врло извјесног страдања сина - са дједа на унука. Улога жене различитих генерација одређује се доменом мајчинства и одгајања дјеце, као и доменом члана породице кога издржава домаћин или уопште стасали потомак (Сад поздрављам ... и моју слатку мајку и рођену, валда је и она Бога молила за юене рођене синове и за юене слатке ранитеље).

У женским писмима, што је видљиво и у формама обраћања, наглашена је брижност, туга због раздвојености, љубавна чежња, заклињање на вјерност, истрајност у одржавању куће и породице у тешким ратним условима и понос на мужа-ратника и јунака, па се у брачним односима, уз наглашено интимна, укључују и ратом условљена патриотска осјећања:

Вељко! Јавио си се оиу, али ти он као кукавичи неће ништа одговорити, нити оће штоо да чује о теби, проклиње те [...]. И ја ти, Вељко, не мислим боље. Свака се жена поноси својим мужем, хвалећи се юеговим јунаштвом, а ти, ти осрамоти и мене и нашу кућу, тако да нас сваки са презрењем гледа. Послала сам ти паре да купиш отрова за њих, како те не би никад више твоје село видјело. То ти је поздрав од Станојке. 40-41.

Начин обраћања екскламацијом имена одражава љутњу и дистанцу адресанта према номинованом адресату, а садржај писма открива разлоге нарушених брачних односа на универзално-друштвеном плану и показују да изневјеравање традиционално-епског кода у коме је улога мушкарца у рату одређена доменом јунаштва и патриотске оданости домовини - не може бити превладано оним потенцијалом који брак подразумијева на интимно-породичном плану. Тако се у низу домена или одредница којима се концептуализује брак и породица у сеоској српској средини времена Великог рата, додају и патриотизам и јунаштво као јаке социјалне детерминате хармоничних брачних односа и уопште епске концепције брака.

Обраћање представницима установа или институцијама са захтјевом типа молбе садржи наглашене изразе поштовања, што уз лексичке јединице показује 
и графичка назначеност у виду великог слова на почетку сваке ријечи, као у писму уредништву часописа „Самоуправа” или у писму краљу:

Многопоштовани Господине Уредниче! Војноплењени Срби, резервни официри аустријски из Бачке, обраћамо се молбом на Вас, имајте доброту слати нам Ваш цеењени лист, да би могли пратити прилике у Србији...134; Поздрављам и молим препокорно Ваме Милостиво Величанство, да замолите велику Русију, браћу нашу, ми Срби већ молимо одавно, да нас пусте браћа нама Руси к вама у помоћ у Србију... 131.

Садржај писама представља молбу, а форме обраћања и поздрављања спадају у наглашено патетичне форме уважавања вишег статуса адресата и изражавања одређене снисходљивости адресанта. У службеним писмима типа протеста или захтјева те нијансе изостају:

Господине Министре! Данас вам је званично саопштено да су ирногорски војници ... У интересу је угледа наше државе да се та ствар испита и да се предузму потребни кораци да наши људи у Болдогасоњу невино не страдају... 73; Господо чланови Комитета, хоћу да вам испричам сан, који сам скоро сањао... 86.

У ,терминалне формуле” спада и крај писма и он најчешће у сељачким писмима изражава жеље за скорим сусретом и добрим здрављем:

Па сад збогом Мишо, и у здрављу да се видимо. 14; Колко има у шумици прута, толико те ја поздрављам пута. Збогом, збогом. 24; У здравље да те затече нама карта. 28; Збогом, и у здрављу се састали. 42; Ништа више него прими срдачан поздрав од свога тате. 48.

Доминатна у форми поздрава на крају писма јесте употреба ријечце збогом, која у датим друштвеним релацијама представља типичан поздрав при растанку.

Интимна писма официра завршавају се на друкчији начин - према већ усвојеном грађанском моделу поздрављања. Сведена су на поздрав и номиновање адресанта - именом, именом и посесивном замјеницом 2. лица, иницијалима и сл.:

Поздрав, Богољуб. 90; Искрен поздрав, мајор Ђ. Ћ. 60; Најискренији поздрав од вамег сина Р. П. 63; Ваш Младен. 62; Љуби те Гавро. 72; Љуби те твој Пјер. 61; Много вас љуби и поздравља ваш Отаи. 74; Грли вас и љуби ваш жељни Љуба. 71; Љуби те и грли твој Ристо. 79; С поштовањем, Н. М. 73.

У поздравној формули завршетка писма често су заступљени и глаголи емоционалних стања љуби и грли, који су уопштени у том говорном чину као знак присности. Уколико је степен присности нижи, поздрав се своди на форму учтивости с поштовањем или на глаголску именицу поздрав и глагол поздравља, уз који се наводи име. Ове формуле којима се писмо завршава обиљежава еналага лица или граматичка синонимија првог и трећег лица, односно ,замјена једног граматичког облика другим, тј. његова употреба на мјесту и у значењу који су својствени том другом облику" (Багић 2012: 96). У писмима се прво лице адресанта, заступљено у наративном дијелу, мијења у 
треће у завршном поздраву. Та замјена остварује се у оквиру перифрастичне конструкције која актуализује породичну улогу (Много вас љуби ваш Oтац = ја; Прими срдачан поздрав од свог тате = ја) или емоционални статус адресанта у односу на адресата, који изражава блискост (Љуби те твој Пјер = ја; Све поздравља, а тебе љуби твој Д. = ја) или дистанцираност, нпр.: То ти је поздрав од Станојке (= ја) - жена се дистанцира од свога мужа, јер га сматра издајником, па је форма поздрава у трећем лицу исказана личним именом, без сродничког апелатива или посесива који изражавају блискост. Тако се у позицији адресанта у односу текста писма и поздрава на крају (или на почетку), успоставља мултиперсонални принцип означавања адресанта посредством више лица - првог и трећег. Прво је лице адресанта као наратора који пише о себи, а треће лице јесте лице које га одређује у односу на адресата - као оца, сина, супруга(у), кума, пријатеља, познаника и сл.

Осим формула којима се отвара и затвара дијалог писма, типичност структуре ратних писама чине и наглашени иницијативни искази којима се адресат подстиче на комуникацију. У тим формулама изражен је захтјев за наставком преписке и њеном фреквентношћу, јер је преписка једини вид везе коју у условима рата и насилне раздвојености војни заробљеници и чланови њихових породица могу да остваре, а и једини контакт заточеника са свијетом ван затвора, егзистенцијално битан. Зато је захтјев за размјеном преписке врло често у писмима заробљеника изразито наглашен и понавља се више пута од почетка до краја писма, као нпр.:

Драга Лало! Још пре 15-20 дана ја сам добио једну твоју карту. Оне су ретке као беле вране. Ја те више нећу опомиьати да пишеш. Кад ти сама не увиђаш потребу честог писања, ја ти то још мање одавде могу доказати. Потреба честог писања неминовна је за човека, који се налази у кафезу већ 2 године. Нас је овамо и Бог заборавио, па заборавите нас и ви тамо [...] Ја те дакле молим пиши ми! Пиши ми сваког дана по десет пута, јер ми је то једини лек да останем здрав у памети. Кад читам твоје карте, онда заборавим мало на све, и тада сам неколико тренутака срећан. Ја те молим, не ускраћуј ми ту једину срећу и задовољство, већ пиши. 79-80.

Те форме најчешће имају облик императива глагола писати (Пишите ми о свему. 60; Пиши ми одмах. 137; Пиши ми ти српски, а адресу латински. 77; Страхиња пиши о твом животу и шта је тамо ново. 91), или питања (Шта је са вама?). Врло често се захтјев износи индиректно (Не јављате се) или у перифрастичном исказу који изражава забринутост због нејављања:

Ја сам писо, не знам већ колико, а одговор не добих никако, је л' нећете или је немогуће. Можда нисте ни ви сад код куће. 49; Ја сам теби већ три карте послао па не знам да ли си добио, јели још нисам добио одговора. 119.

Нередовност преписке са породицом и пријатељима, заробљеним српским војницима неопходне, условљена је врло често цензуром коју проводе и аустроугарске команде или команде војске на чијој територији се налазе војни заробљеници, као и војне службе Србије, а чега су заробљеници свјесни: 
Гредиг, 14. јула 1915.

Од кад сам овдје, пишем ти сваког дана. То ми је највеће задовољство и још веће да од тебе добијам карте. Ти ми пишеш. пишеш ми сваког дана, ја то знам. Али те карте, твоје карте ја не добијам, а и ти моје такође. Шта је томе узрок и какав је разлог за то. Никакав! Нехат, да се прочитају те карте, ради иензуре, и види њихова наивна и чисто фамилијарна садржина која може свуда ићи и проћи; али, нехат, да се читају, са њима се најсвирепије поступа; ниште се и баиају, и те карте несуђене, наивно гину, ужасно гину, мучки гину [...] Ретко ко добије карте. Од 15. маја до 22. јула нисам добио ни једну карту. Пропале су 34 и 35 од твојих. Ипак сваки дан ми пиши и ја ћи теби. Љуби те твој Пијер. 61.

Сва ратна писма са разних територија подлијежу вишеструкој цензури, јер се у писмима преносе не само интимно-фамилијарне него и информације о положају војних снага, о условима у јединицама и логорима и сл. - све оно што одређена зараћена страна мора да сакрије од непријатеља. Писма заробљеника често су и фалсификована од стране аустроугарске цензуре, како би се у њих уметнутим питањима прибавиле информације о положају српских јединица. То експлицитно наводи и В. Пандуровић, у пропратном тексту уз писма: „23. априла 1915. старешина цензора српске групе предложио је ц. и кр. ратном министарству, да се српским заробљеницима и интернирцима дозволи неограничено дописивање. Овај предлог образлаже тиме, да је он започео једну акцију, помоћу које би се из српске кореспонденције дало лако утврдити размештање српске војске у Србији. Он познаје психу Срба. Од јужних Словена, у њих је најјаче развијен култ породичног живота. Њихова је слабост да тешко подносе заробљеништво и одвојеност од фамилија, те жуде за што чешћим писменим саобраћајем [...] На тај начин би створен у крилу Црвеног Крста један читав систем шпијунаже помоћу преписке ратних заробљеника." (Пандуровућ 2014: 97). Из тих разлога, већ тада се укида забрана употребе ћирилице, на којој је и иначе велики број писама - што из разлога непознавања латинице од стране великог броја адресаната, што из патриотских разлога:

Piši mi ti srpski, a adresu latinski. 77; Маро, да ми пишеш српски, јер сам ја Србин, па нека дође ма која држава у Србију, ја сам Србин, и као Србин ћу да умрем; ако ми српски не пишеш, немој да ми пишеш више. 90.

Свјесни чињенице да се њихова писма вишеструко злоупотребљавају од стране непријатеља, заробљеници често прибјегавју формама езотеричног исказа, разумљивог само између њих и оних којима је писмо намијењено. 


\section{3. СЛИКА СТВАРНОСТИ У ОТВОРЕНОМ И МИМИКРИРАНОМ ИСКАЗУ}

У отвореном исказу са дословно референцијалним значењем и затвореници и чланови њихових породица пишу о тешким ратним приликама, о сиромаштву, глади, болести, смрти, као и о осјећањима туге због раздвојености и чежње за сусретом са породицом. Тај тематски круг предодређује суровост свјетског рата, посебно тешка у Србији и за Србе који су се или као заробљени припадници аустроугарске војске, или српске, или као интернирци нашли по логорима у Аустрији, Њемачкој, Чешкој, Пољској или у Русији. Писма која размјењују са члановима породица осликавају и социјални и интимни свијет породица које живе у ратној Србији, у којој се жене и старци боре за егзистенцију породице, а у којој харају сиромаштво и смрт:

Земљу сам дала за кукуруз Тоши на пола да ради [...] и овце сам још зимус продала, и продала сам ону стару кравииу, а ону млађу Калушу и ону матору краву, те две нећу да продам ... а кобилу сам дала код мог брата да је рани и да ради на юу док ти кући не дођеш. 18; Овамо је велико давање, велики порез; казане су нам покупили; ракије нема и што је имало то је покупьено; кукуруз је слабо, јер је била суша, а и њега купе. 125; Поздрављам те тавним гласом и болесним. Жарко ми је умро већ девет месещи, а Даринка је трећи месеи како је умрла. И свуда сам лека тражила, и нигди јим лека нашла нисам [...] Еј, Боже, морам умрети од терета тешког! Како кукам и плачем, да никад лица не сушим. 16.

У писмима се износе детаљи из породичног живота - о сјетви, о наметима које сељак даје за српску војску или за непријатеља на поробљеној територији, а у изливу осјећања и размјени информација ствара се слика да српску породицу у времену Великог рата карактерише: породична хармонија патријархата у коме се поштују ауторитети, изражава се и његује љубав према родитељима, супружницима и дјеци, браћи и њиховим породицама који живе још увијек у неподијељеним породичним задругама, заштитнички однос према неудатим сестрама, поштовање према ширем кругу сродника и кумова, као и према комшијама. Такође се из преписке, посебно из писама која се шаљу из Србије, ишчитава и неугасли виталитет духа народа, изражен кроз наду да страдањима мора доћи крај и кроз жељу и вјеру да ће се раздвојени чланови породице поново окупити:

Ми молимо Бога, за бабу намега, да нам кући дођеш, да се искупимо, да једно, Тошо, другог не желимо. 17.

Писма Срба заробљеника много су песимистичнија, што условљава дуг боравак у логорима, изолованост од свијета и нељудски услови у којима је тешко преживјети, о чему се пише са горчином и иронијом:

Овамо је била велика болест и много је помрло Црногораща, а Србијанаца ни броја се не зна. У нашем лагеру од 12 хиљада умрло је више од 5 хиљада, у другијем логорима умрло је од 16 хиљада по 9 хиљада, па по томе можете иијенити каква је болест међу 
нама била. Ја сам боловао 2 и по мјесеиа од тифуса, али да сам бијо сретан не бих ни преболијо. 63; Нама лична безбедност, овде где смо, потпуно је од спољњег света осигурана јер поред приљубљене ограде од дасака од 3 метра са поврх юе два реда бодљикаве жиче и јоште јака стражарска посада; те нам хвала Богу ово омогућава да гледамо у небеса и околне врхове брда. 62; Ја вас молим као Бога да ми то учините, јер се много мучим, као Јуде што су Христа мучили, ја се мучим гладан, 7 дана и кило леба, а одела на мени ништа нема, већ са леђа кожа спада, а из нога крвиа лије, кад у вече легнем, земьа ми је простирач, а небо покривач, а мила стена поглавач, ја вас молим да ми испратите 2 кошуље дугачке, 2 чарапе, појас, копоран и шешир. 88. Видим да се овај рат отегао у бесконачност и ако будемо принуђени још једну зиму остати, пола односно три четвртине помреће овде, иначе смо већ постали сенке и сваког дана умиру по пет од глади и зиме. 85. Живимо у дрвеним баракама, опкољени смо високим плотом, чувају нас стражари. Благо мртвима. 69.

Због цензурисања писама од стране аустроугарске војне власти, много је више података о теретном преживљавању у логорима дато у мимикрираном изразу, па се и једна од њихових типичност огледа и у формама и стилистици прикривене информације, засноване на асоцијацијама које су на основу карактеристика референта разумљиве само адресанту и адресату:

Лепо живимо, исто онако као болесници у топчидерском санаторијуму, наравно они имају више слободе но ми, али то се не може замерити, јер је то било у мирно време, а сада је рат. 68. А како је са мном сиромахом било у Петроварадинском пансиону - као онај у Нишу преко пута Нишавске тврђаве. 77. Твојим трагом ишло је више људи, и нико није успео. Неуспех им је донио рђаве последице 69. Страшни се облаци спремају над нама, буре ће бити, како ћемо проћи, Бог ће знати. Очекујемо посљедњи час. 47. Преболео сам две опасне болести; сад болујем од силне чежне и жеље да дођем тамо, да се дочепам пушке и да будем неумољив и без сриа према овим „културним”. Јом се зуика о неком пријатељству и савезу! Пазите шта ви тамо радите! Пишите ми о свему, макар завијено, па ћемо одгонетати. 60. Знам шта сад радиш-освети јој се и за ме, и мени је на жао учинила та банкротирана бабускара. Чуо сам доста шта јој се догодило, али она нема стида. 69. Мени дође те би из гласа куко од овог добра. 75. Ја видим да је се са јужне стране млого наоблачило и велики облащи и кроз који час оће велика киша и облаци, и облаци отићи на север кад киша престане вода ће потекнути куда је и текла. Ја видим да ви тамо слабије видите да оће киша и вода тећи куда била али ја вам кажем причекајте мало и ви и ми. Кад добијете карту, одговорите јесте ли добили и разумели. 83.

Ови и слични примјери представљају алузивно-криптографски текст, заснован на истом тајном коду, тако да поређење буде познато и пошиљаоцу и примаоцу (Лепо живимо, исто онако као болесници у топчидерском санаторијуму; А како је са мном сиромахом било у Петроварадинском пансиону - као онај у Нишу преко пута Нишавске тврђаве) и да се на основу њега ишчита слика животних услова и страдања у њима, али да се то не каже отворено, jep hе у противном писмо бити уништено од стране цензуре. На овај начин се одашиљу и поруке упозорења (Твојим трагом иило је више људи, и нико није успео. Неуспех им је донио рђаве последице), или жеље за осветом непријатељу, исказане иронично-метафоричним или метонимијским помјерањем значења, па се Аустроугарска замјењује са иронично конотираном особином 
„културни” или метафором „банкротирана бабускара” (да се дочепам пушке и да будем неумољив и без сриа према овим ,културним”; освети јој се и за ме, и мени је на жао учинила та банкротирана бабускара). Да би се реферисало о (са)знањима о великим биткама и страдањима и упозорио адресат на њих, адресант користи и типичне метафоре у којима тај садржај замјењује лексика која представља велике временске непогоде „велике кише” и „страшни облаци”, „буре” (Страшни се облаци спремају над нама, буре ће бити; Ја видим да је се са јужне стране млого наоблачило и велики облачи и кроз који час оће велика киша и облаци, и облаци отићи на север кад киша престане).

У условима у којима се налази већина адресаната анализираних писама, непосредно и посредно се обликује топос заробљеника, као најдоминантнија тематска улога у оквиру релације адресат - адресант. То је улога која „дефинише актера. Постоје професионалне улоге (лекар, учитељ, сељак, поп итд.), породичне (отац, маћеха, старији брат итд.), психосоцијалне (педант, сноб, параноик итд.)" (Принс 2011: 201). У Писмима се разне професионалне и социјалне улоге којима је представљен адресант - официр, војник, учитељ, сељак, родитељ, супруг, син и сл. обједињују у једну, у јединствен социјалноисторијски одређен концепт ратног војног заробљеника. А његову доминантност у тексту Писама у цјелини показује и разноврсно лексичко денотирање тог појма које се реализује у више синонимских или ортографско-ортоепских варијанти исте лексеме. То различито именовање појма затвореник условљено је просторно-временским специфичностима средине у којој се његов статус реализује. Тако писма из њемачког говорног подручја неријетко садрже одредницу логоращ, од њемачке ријечи La'ger, што значи „војни логор” (Кангрга 1975: 402). Богатством ортоепско-ортографских варијаната, према утицају руског језика - у коме военнопленный значи „ратни заробљеник” (Грујић 1969: 63) - одликују се писма из Русије (военнопленни, 179; военнопљенни, 142; военоплени, 166; војенопьени, 171, војноплени, 152, војнопљенени, 182; военопљен, 199; војнопљен, 180; военно пленнени, 179, војно плијен, 202; војни пљен, 181; воен. плениј, 200; воено-плен, 180; војнопљеник, 178). У ьима се тај појмовни садржај изсказује и перифразом (плен Русије, 141; у Русији у пљену, $153 ;$ плијену Русији, 151). У Писмима су заступљени и синоними затвореник, робијаш и сужағ. Свака од датих варијаната подразумијева исту архисему присилно одузете слободе коју садржи у савременом језику најнеутралнија од њих, затвореник или у језику првих деценија 20. вијека исто тако неутрална и фреквентна ријеч, робијаш, док остале семантизује контекст конотацијама које носи - просторне идентификације (Њемачка или Аустроугарска, односно Русија) или компоненте емоционално-експресивног става (сужаљ).

Без обзира у ком дијелу зараћеног свијета се одвија заробљеников живот, његов положај одређен је као понижавајући, тежак и неиздржив, с тим да је нешто лакши за оне који су се нашли у руском заробљеништву. Нељудске и 
надљудске димензије трпљења, обесправљености чак и од стране свјетски познатих институција за заштиту права и хуманости, као што је Црвени крст, рефлектује алегоријски дат приказ положаја Срба у аустроугарским логорима, у писму логораша упућеном Црвеном крсту у Женеви, у коме се положај заробљеника представља као трпљење коња које газда пази зависно од њихове намјене - најбоље храни јахаће, а најгоре „коње из плуга”, којима су „усне отекле од надувених зазубица, што су их добили гледајући оне друге коње, гдје једу доста зоби, пак само брехћу!” (86-87). Иако је врло често свјестан безнадежности ситуације у којој се налази, осим жеље да се поново нађе у породичном окриљу, вјера у Бога и патриотизам ратном војном заробљенику најјачи су мотив за преживљавање. Бројни су примјери родољубља расути по писмима војника и официра:

Најсрећнији је мој Командант Пуковник Б., што је оног дана, кад сам ја заробљен, погинуо и не гледа више јад и чемер Српског Народа и своје породице; али моја је непоколебљива вера у Бога, да ће у најкраћем времену синути суние слободе Српском Народу и остатак неуништеног у миру, слави и великој Србији живети. Бог је с нама и ја му се молим. 71; Нису српски народ упропастили радикали, нити ће га упропастити Аустријании; већ њега упропашћују они од кога си ти тако нешто могла да чујеш. Нека знају те вуцибатине, да званична Србија још постоји и то већа, моћнија и силнија него што је била пре рата. 90; Маро, да ми пишеш српски, јер сам ја Србин, па нека дође ма која држава у Србију, ја сам Србин, и као Србин ћу да умрем; ако ми српски не пишеш, немој да ми пишеш виме. 90; Јуче, баш на дан једногодишњице мобилизације када сам упрљао своје тело оделом наших вековних тирана, стигао сам у нашу милу нову домовину Србију. Једва чекам да обучем униформу и лупим сабљу Шваби по юушии. Па зар може Србин друкче мислити? 112; О, сад тек осећам да сам Србин! Овде је, Сејо моја, нам прадед пао, овде где је правда погнуте главе пратила столећа сада стоји подигнуте главе Српски Војник, међу тим људима се и ја налазим, замисли моју срећу па ми и ти буди радосна. 116; Синоћ стигосмо влаком овде, данас одлазимо даље, сигурно за Ниш. Моја последња жеља на овом свету је, у овом часу је до крајности испуњена, кличем свом Господу Богу: велика ти хвала! Идемо, љубљени моји, напред, те шта Бог да! 117; Молим се свемогућем Богу да ме врати у крило мајке Србије [...] Чекам дан кад ћу чути да ми је слободан пут у Србију. Дођем ли још једном у Србију, никада више никуда. Тамо ми је живети, тамо ћу умрети. 133.

Патриотизам српског војника и војног заробљеника концептуализује се у схватању Србије као славне и велике, моћне и када страда (Нека знају те вуциибатине, да званична Србија још постоји и то већа, моћнија и силнија него uто је била пре рата). Осликава се и идентитетским доменом припадности појединца народу који се идентификује ћирилицом као националним писмом (ако ми српски не пишеш, немој да ми пишеш више), доменом слободарског духа - оличеним у његовој жељи да се бори за слободу (Једва чекам да обучем униформу и лупим сабљу Шваби по юуищи. Па зар може Србин друкче мислити?), у његовој оданости Србији као мајци (Молим се свемогућем Богу да ме врати у крило мајке Србије) и жељи да у Србији и за Србију и живи и умре (Дођем ли још једном у Србију, никада више никуда. Тамо ми је живети, тамо ћу умрети). 


\section{4. ЗАКЉУЧАК}

Анализирани корпус - који чини лична преписка српских војника и ратних заробљеника који су се током Првог свјетског рата нашли у логорима Аустроугарске монархије, као и Срба аустроугарских војника, који су пребјегли у Србију или у Русију, или су тамо заробљени - карактеристичан је по томе што су у њему писма различитих адресаната обједињена настанком у истим друштвеним околностима и истим тематским кругом тако да обликују за дато вријеме и дате појаве универзално-објективну слику свијета и када су појединачно интимне природе. Поглед на свијет у оквиру тако формираног циклуса не успоставља се у дијалогу на релацији адресант - адресат, него у полифонијском дијалогу гласова, свијести и тачки гледишта различитих адресаната који непосредно доживљавају ситуацију коју у форми писмима обликују. Зато се у анализи издвајају типични дискурс-маркери и тумачи њихова структура и значења у ширем социокултурном и тематском оквиру - у коме се, ситуацијски моделовани, издвајају и концептуализују топоси заробљеника, породище, брака и патриотизма као егзистенцијално најбитнији и адресанту и адресату у условима њихове насилне раздвојености.

Концепт породице почива на метафори куће и обухвата још увијек неподијељену патријархалну заједницу више генерација, саграђену на породичном имању и повезану хијерархијом традиционалних односа, топлином и међусобним поштовањем. Брачни живот војника и заробљеника интегрални је дио шире породичне цјелине, што јасно одражавају формуле поздрављања којима се отвара писмо. У писмима се као најдоминантнија, од тематског значаја, издваја улога ратног војног заробљеника, јер се слика свијета представљена у писмима, најчешће изводи из тачке гледишта тако одређеног адресанта или у односу на њега. Зато се та улога поставља као топос у корпусу, па је и лексичко-семантички, у оквиру исте архисеме присилно одузете слободе, врло разноврсно номинована (затвореник, заробљеник, робијаш, сужағ, војнопљењеник, логораш, итд.), будући да именовање рефлектује конотације емоционално-експресивне или просторне идентификације (заробљеништва у аустријским или руским логорима). Српског ратног војног заробљеника из Првог свјетског рата карактерише, с једне стране, страдање и трпљење у условима тоталне егзистенцијалне угрожености, а с друге стране - неуништени виталитет духа који се темељи на љубави према ближњима и патриотизму, који се концептуализује суштинским идентитетским цртама - националним писмом и исконском оданошћу Србији као мајци, као циљу за који се и живи и умире. 


\section{ИЗВОРИ}

Пандуровић 2014: В. Пандуровић, Српска писма из Светског рата 1914-1918, Нови Сад - Београд: Прометеј - Радио-телевизија Србије.

\section{ЛИТЕРАТУРА}

Багић 2012: K. Bagić, Rječnik stilskih figura, Zagreb: Školska knjiga.

Бахтин 1980: М. Бахтин, Проблем говорних жанрова, Трећи програм, бр. 47, Београд: Радио Београд, 233-270.

Грујић 1969: Б. Грујић, Руско-српскохрватски школски речник, Титоград: Графички завод.

Кангрга 1975: J. Кангрга, Немачко-српскохрватски речник, Београд: Просвета.

Ковачевић 2000: М. Ковачевић, Стилистика и граматика стилских фигура, Крагујевац: Кантакузин.

Поповић 2000: Љ. Поповић, Епистоларни дискурс украјинског и српског језика, Београд: Филолошки факултет.

Принс 2011: Џ. Принс, Наратолошки речник, Београд: Службени гласник.

PMC 2007: Речник српскога језика, Нови Сад: Матица српска.

PСАНУ 1966: Речник српскохрватског књижевног и народног језика, књ. IV, Београд: САНУ.

РСГВ 2000: Речник српских говора Војводине (редактор Д. Петровић), Нови Сад: Матица српска - ИК Тиск цвет.

ÜBER DIE EIGENSCHAFTEN DES EPISTOLARISCHEN DISKURSES IN DEN BRIEFEN DER SOLDATEN UND GEFANGENEN AUS DEM ERSTEN WELTKRIEG

Zusammenfassung

In der Arbeit werden, auf Grund der dekriptiv-strukturellen und kognitiv-konzeptionellen Methoden, die persönlichen Briefwechesel der serbischen Soldaten, Kriegsgefangenen, die sich im Ersten Weltkrieg in der Gefangenschaft in Konzentrantionslagern der Österreich-Ungerischen Monarchie befanden, sowie von serbischen Soldaten bei derÖsterreich-Ungerischen Monarchie, die nach Serbien oder Russsland geflohen sind, oder 
dort verhaftet wurde, analysiert. Den Korpus zeichnet die Besonderheit aus, dass in ihm Briefe von verschiedenen Absendern zusammengestellt wurden, die in den gleichen gesellschaftlichen Umständen und den gleichen Themenkreisen enstanden sind, und die für die damalige Zeit und die damaligen Umstände ein universell-objektives Weltbild, auch im persönlichen Sinn, abgeben. Die Weltansicht besteht in so einem zusammgestellten Zyklus nicht aus Dialogen auf der Relation Absender-Empfänger, sondern aus polyphonischen Dialogen von Stimmen, pers. Bewusssein, und unterschiedlichen Ansichten von verschiedenen Absendern, die Situationen direkt erleben und in Form von Briefen wiedergeben. Das ist auch der Grund, warum bei der Analyse typische Diskusmarker aussortiert werden, und ihre Struktur und Bedeutung in einem breiteren sozial-kulturellen und thematischen Rahmen analysiert werden, in denen die Toposeder Gefangenen, der Familien, der Ehe und des Patriotismus, situativ modelliert, ausgesondert werden als die existentiell entscheidenden für Absender und Emfänger in den Umständen ihrer gewaltsamen Trennung.

Schlüsselwörter: epistolarischer Diskurs, das Genre, der Empänder, der Absender, Dialog

Milanka J. Babić 